Doi: HTTPS://DOI.ORG/10.23910/IJBSM/2018.9.2.3C0550

\title{
Importance of Sustainable Agriculture in Tribal Community of India
}

\author{
Jitendra Patidar ${ }^{*}$, Bherulal Kumhar ${ }^{1}$, Suresh Mhaske ${ }^{1}$ and Seema Jat ${ }^{2}$ \\ ${ }^{1}$ Jawaharlal Nehru Agricultural University, Jabalpur, Madhya Pradesh (482 004), India \\ ${ }^{2}$ Sri Karan Narendra College of Agriculture, Jobner, Rajasthan (303 328), India
}

\section{Corresponding Author}

Jitendra Patidar

e-mail: jitendrapatidar90-coaagr@pau.edu

\author{
Article History \\ Article ID: $3 \mathrm{C0550}$ \\ Received in $21^{\text {st }}$ October, 2017 \\ Received in revised form $19^{\text {th }}$ December, 2017 \\ Accepted in final form $26^{\text {th }}$ March, 2018
}

\begin{abstract}
The sustainable livelihood synthesizes all human activities including five core assets: physical, natural, financial, human and social capital upon which the livelihoods are built.The sustainable livelihood approach aims to find out about livelihoods to improve the design and implementation of poverty reduction efforts. The livelihood assets status of the tribal people in the state of India is the resultant outcome of collective performance of independent variables such as socio-personal (age, education, social participation and family composition), economic (size of land holding, main occupation, housing status, farm power, farm implements, livestock possession, material possession, income from forestry and gross annual income), psychological (level of aspiration, knowledge about forestry practices, adoption of forestry practices and attitude towards forestry), communication (extension contact and use of information sources) and situational (employment status, migration status and utilization of forest resources). The Jharkhand state is bestowed with rich natural resources, abundant biodiversity and excellent human resouvrces. Forest based livelihoods by the tribal people mainly revolve around collection, processing and utilization/selling of various NTFPs like fuel wood, lac, tooth brush, leaves for plate and cup making, fodder and browse, vegetables, fruits, seeds, flowers, bamboos, medicines, mushrooms, oilseeds, oilseed cake, spices, honey, oils, gums, resins, gum-resins, dyes, wax, brooms, fibers, floss, silk, charcoal, fencing, wildlife products, thatches, baskets, ropes, mats, handicrafts, pickles, beverages, abiotic products etc.
\end{abstract}

Keywords: livelihood, forest, sustainable production and integrated farming

\section{Introduction}

The concept of sustainable development emerged in the 1980s. It propelled a paradigm shift in development thinking, and continues to dominate the developmentdiscourse at various levels, from the local to global. The best explanation to sustainable development was given by the World Commission for Environment and Development (The Bruntland Commission) in its 1987 report, 'Our common future', as, 'the ability to meet the needs of the present without compromising the ability of the future generation to meet their own needs' (Mishra, 2005).

For economic sustainability analysis, change in overall crop production and stability of crop production were the indicators used. Employment of rural labor force and food security were indicators used for social sustainability analysis. The findings from the analyses revealed a tendency towards unsustainable agricultural production in all provinces. This was caused by overuse of inorganic fertilizer, pesticides and groundwater for irrigation in Sindh and Punjab (Zulfiqar and Thapa, 2017).

The tribal communities have been traditionally practicing shifting cultivation of subsistence crops supplemented by collection of forest materials.

Destruction of forests due to commercial over-exploitation over the last 3 to 4 decades has decreased the productivity of the soil due to extensive soil erosion and reducing the capacity of land to rejuvenate and affecting natural vegetation and water resources. This has severely threatened the wellbeing of the tribal community which depends on agriculture and forest, forcing them to be bonded and migrant labour; increasing their indebtedness; and exploitation of forest produce for income.

As a tribal farmer, Due to continuous poor yield and often erratic rainfall, farmers and especially youths started losing faith in agriculture to sustain their livelihood.

The concept of livelihood is rapidly gaining acceptance as a valuable means of understanding the factors that influence people's lives and well-being. 'It is comprised of capacities, assets, and activities required for means of living. A livelihood will be sustainable when it can cope with and recover from stress and shocks and maintain or enhance its capacities and assets, both now and in the future, while not undermining the natural resource base' (Carney, 1998). Sustainable livelihood 
is a way of thinking about the objectives, scope and priorities for development, in order to enhance progress in poverty elimination. Sustainable livelihood aims to help poor people achieve lasting improvements against the indicators of poverty that they define.

\section{Materials and Methods}

Jharkhand literally means 'forest region' where forests play a central role in the economic, cultural and socio-political systems and the entire lives and livelihoods of a majority of the people revolve around forests and forestry. Non-timber forest products (NTFPs) play an important role in supporting rural livelihoods and food security in Jharkhand. Livelihoods are ways of keeping one self meaning fully occupied by using one'sendowments (human and material) to generate adequate resources to meet the requirements of the house hold in a sustainable manner (Bernstein, 1992). Livestock contributes to food, economics, environment, health, education, society, infrastructure, nutritional security and thusin total to the livelihood security of tribes by providing transport and on-farm power. Sustainable livelihood approaches are genuinely trans-disciplinary as they are produced, disseminated and are applied inthe border land between research, policy and practice (Knutsson, 2006). The natural system possesses self-regulating mechanisms, which are composed of a complex web of positive and negative feedback systems operating within the context of the carrying, regeneration, and assimilation capacity of the respective systems. Mobility of plants and animals, as an essential element of self-regulation of the biotic system, has played a major role in the evolution of the planet Earth. As an integral part of the animal kingdom, mobility governed by ecological factors has patterned the dominant lifes tyle of man kind for millions of years. Dairying contributes to food, economic, environmental, institutional, health, educational, social, infrastructural, nutritional security and thus in total to the livelihood security of tribes by providing transport and on-farm power. Dairy animals manure helps in maintaining soil fertility; they fulfill a wide range of socio-cultural roles of tribes. Eventhe poorest of the poor tribes often have dairy animal that cansave them along a pathway out of poverty. Small farmer havedairy animals with low milk productivity, low milk price and shortage of quality breed animals as major constraints (Rani et al., 2013). The advantage of using a livelihood approach as a basis for analysis is that it can provide structured thinking and a sound analytical basis on which to ground interventions and identify opportunities for improved assistance. Better understanding of livelihoods could lead to enhanced analysis and programme design that is more responsive to opportunities and more focused on addressing actual vulnerabilities and threats faced by communities. The emphasis on holistic approach does not exclude a sectorial focus. It can help people who undertake sectorial projects to understand and build links with other sectors. The livelihood approach helps to create insight into how sectorial initiatives have an impact on people's livelihoods, and into how people respond tosectorial initiatives.

\section{Results and Discussion}

The livelihood of tribal communities in the area has traditionally been dominated by pig-based production systems poultry, goat rearing and artisan activities also played a vital role in the livelihood of tribal people. These all are found to be substantially contributing for the sustainable livelihood of the respondents and are the integral part of day to day livelihoodactivities, nutritional security and traditional lifestyle of tribal people in the area. Formulation of policies on sustainable livelihood of tribes ensured a number of rights and concessions for tribal people. Therefore the livelihood promotion among tribal people needs a paradigm shift focusing on pig production system to keep pace with sustainable development and poverty elimination in the area (Mukesh kumar et al., 2015).

Research amongst host communities in western Tanzania (Whitaker, 1999) focused on changing opportunities faced by host communities. The study concludes that the influx of refugees created a new context in which hosts devised strategies to gain access to incoming resources and to maintain access to their own resources. Differing strategies and structures allowed some hosts to benefit while others became worse off. The broad pattern which emerged out of this study was that hosts who already had access to resources or power were better poised to exploit the refugee situation. While hosts who were already disadvantaged in the local socio-economic structure, struggled to maintain access to even the most basic resources and thus became further marginalized.

In this regard, the Situation Analysis Study of Indian farmers conducted by NSSO as a part of Millennium Study of Union Ministry of Agriculture, has brought out some highly relevant and interesting results, some of which are: (i) An estimated 27 per cent of the farmers do not like farming because it is not considered profitable, (ii) Nearly $40 \%$ of the farmers, if given a choice, would prefer to take up some other career (iii) There is very low level of awareness among farmers about the modern eco-friendly technologies like use of bio-fertilizers, IPM and IPNM as well as of government programmes like MSP, crop insurance and agri-export promotion, (iv) Many farmers have reported non-availability of modern inputs within the villages, (v) Small holder's dependence for livelihoods on dairying and other animal husbandry activities is higher than that of not-so-small farmers, (vi) Nearly $50 \%$ of farm households are indebted and the ratio as well as average of outstanding loan per farm household are higher in relatively more developed states like Punjab, Tamil Nadu and Andhra Pradesh, (vii) There is a considerable variation in per capita expenditure of farmhouseholds across the states, Kumar et al., 2006. 
The study leads to conclude that the livelihoods of tribal communities in the area have traditionally been dominated by subsistence agriculture. However, the forest resources play a vital role in the livelihoods of tribal people through direct paid employment and NTFPs based self-employment. There is enormous scope in improvement of NTFPs based livelihoods for tribal population through proper storage and value addition to NTFPs, domestication and commercialization of NTFPs, organized marketing system, proper refinement and dissemination of indigenous technologies, institutional support in training and skill development, appropriate extension and communication networks and exploring new forest resources based livelihood avenues through wood and NTFPs based secondary employments in the area, Islam et al., 2013.

The path analysis revealed that the social participation, level of aspiration and gross annual income were the crucial variables for livelihood assets status. To make livelihoods of tribal people stronger and sustainable, the contributor variables of livelihood assets status must be improved to accelerate the forest resources based livelihood diversifications, promotion and development, Islam et al., 2014.

The study signified that despite inhabiting in resource rich areas, the tribal people are in underprivileged position in all respects as reflected by their low socio-personal and economic status and poor employment opportunities. The prevailing scenario led to the repercussions like acute poverty, malnutrition, migration, substandard life quality, debt, unrest, naxalism, isolation from national mainstream, lack of awareness and exposure, traditional severity etc. The forests play a central role in the economic, cultural and socio-political systems and the entire lives and livelihoods of a majority of the tribal people in the area, Islam et al., 2015.

An effective management of the entire NTFPs collection is a key factor for a successful commercialization of NTFPs in the global market. These include processing and marketing skills, promoting the domestication of NTFPs, provision of credit to NTFPs farmers, prevention of deforestation, effective promotion of NTFPs, up-scaling research on NTFPs and development of NTFPs policy to guide the production, harvesting, domestication and marketing of the products. Improving the management of NTFPs collection in the country will enormously help to boost employment and incomegeneration opportunities, enhance food security and improve the livelihoods of farmers, their families, and communities, Verma and Paul, 2015.

Contrary to the dominant belief of attributing ecological disaster exclusively to the industrial society, there is strong historical evidence that ecological factors were key elements in the rise and fall of ancient civilization and in two of the major social transformations, namely, the agricultural and industrial transformations. An in-depth look at the different religious teachings, medieval philosophies, and traditional beliefs as the major repositories of human knowledge besides modern science reveals that, aside from the variation in semantics, most of them contain a strong component of livingin harmony with nature and with one another. This is the logical essenceof what we, today, call sustainability, Desta Mebratu, 1998 (Figure 1).

However, research (Jacobsen, 2002) has shown that many refugees cannot establish or maintain their livelihoods because they cannot exercise the rights to which they are entitled under international human rights, humanitarian law, and/or refugee law. Often, refugees suffer from the absence of civil, social and economic rights including freedom of movement and residence, freedom of speech and assembly, fair trial, property rights, the right to engage in wage labor, self-employment and the conclusion of valid contracts, access

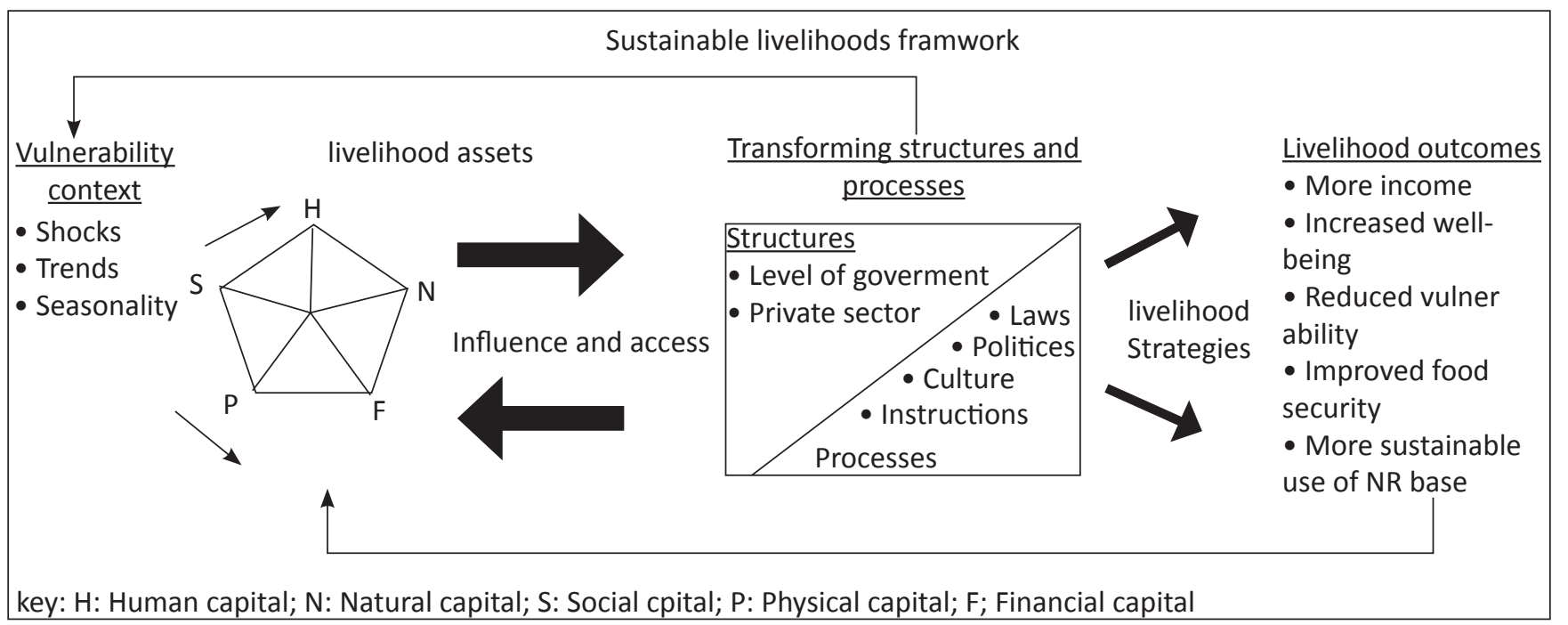

Figure 1: Sustainable livelihoods framework (Source Mukesh Kumar, Jancy Gupta and Aparna Radhakrishnan, Sustainability of dairy based livelihoods of the tribes in Ranchi and Dhanbad districts of Jharkhand; Indian Journal of Dairy Science 69(2), 2016 
to school education, access to credit; protection against physical and sexual abuse, harassment, unlawful detention and deportation.

In fact, Bennett and Franzel (2009) provide the best example of how the Sustainable Livelihoods Framework itself can constitute the conceptual framework for a meta-analysis. They scrutinized 32 underlying studies from Africa and Latin America on the capacity of organic and resource-conserving agriculture to improve the livelihoods of poor smallholders. Although it was often argued in the past that the Sustainable Livelihoods Framework should not be used as a rigid prescription for interventions or research, it becomes clear from this study that a uniform approach does enable meta-conclusions to be drawn. But that is only the first step (Figure 2).

\begin{tabular}{|c|c|}
\hline $\begin{array}{l}\text { skills, know } \\
\text { health and }\end{array}$ & $\begin{array}{l}\text { Human capital } \\
\text { vledge, labor (includes good } \\
\text { physical capability) savings, } \\
\text { and other }\end{array}$ \\
\hline $\begin{array}{l}\text { Natural capital } \\
\text { natural resource stocks } \\
\text { (soil, water, air, genetic } \\
\text { resources etc.) and } \\
\text { environmental services } \\
\text { (hydrological cycle, }\end{array}$ & $\begin{array}{l}\text { Economic or financial } \\
\text { capital } \\
\text { capital base (cash, credit/ } \\
\text { debt, economic assets) }\end{array}$ \\
\hline $\begin{array}{l}\text { Social capital } \\
\text { Social resources (net- } \\
\text { works, social claims, so- } \\
\text { cial relations, affiliations, } \\
\text { associations) }\end{array}$ & $\begin{array}{l}\text { Physical capital } \\
\text { Infrastructure (buildings, } \\
\text { roads), production equip- } \\
\text { ment andtechnologies) }\end{array}$ \\
\hline
\end{tabular}

Figure 2: Five capitals of sustainable livelihood, (Scoones, 1998).

\section{Conclusion}

Sustainable livelihood is a way of thinking about the objectives, scope and priorities for development, in order to enhance progress in poverty elimination. The livelihood approach was also attractive because it had an open eye for the wider context in which the poor organized their livelihood strategies. This wider context was considered fundamental because an important part of the poverty alleviation policies. If these policies could become more effective, it would bring the poor less vulnerability, more well-being and more sustainability.

\section{Reference}

Bennett, M., Franzel, S., 2009. Can organic and resourceconserving agriculture improvelivelihood? A metaanalysis and conceptual framework for site-specific evaluation. ICRAF, Occasional Paper 11, Nairobi.

Bernstein, H., 1992. Rural livelihoods: crises and responses. Oxford University Press,Oxford in association with Open University.
Carney, D., 1998. Sustainable Rural Livelihoods, What Contribution Can We Make? Nottingham: DFID.

Desta Mebratu, sustainability and sustainable development: historical and conceptual review environmental impact assess rev. 1998; 18, 493-520.

Islam, M.A., Quli, S.M.S., Rai, R., Sofi, P.A., 2013. Livelihood contributions of forest resources to the tribal communities of Jharkhand, International Journal of Fundamental and Applied Life Sciences 2013, 3(2) AprilJune, 131-144.

Islam, M.A., Qulis, M.S., Rai R., Ali, A., 2014. Exploration of Variables Predicting Livelihood Assets Status ofTribal Communities Subsisting in Forests of Jharkhand, India J Hum Ecol, 47(3), 241-249.

Islam, M.A., Rai, R., Quli, S.M.S., Tramboo, M.S., 2015. Socioeconomic and demographic descriptions of tribal people subsisting in forest resources of Jharkhand, India. Asian Journal of Biological Sciences 10(1), 75-82.

Jacobsen, K., 2002. Supporting displaced livelihoods: the economic impact of protracted conflict and displacement, Lessons Learned from Four Microenterprise Interventions.

Knutsson, P., 2006. The sustainable livelihoods approach: a framework for knowledge integration assessment, Human Ecology Review 13(1), 90-99.

Kumar, M., Gupta, J., Radhakrishnan, A., 2016. Sustainability of dairy based livelihoods of the tribes in Ranchi and Dhanbad districts of Jharkhand, Indian Journal of Dairy Science 69(2).

Kumar, M., Gupta, j., Radhakrishnanand, A., Singh, M., 2015: Pig-based production system contributing towards thesustainable livelihood of tribes of Jharkhand, International Journal of Farm Sciences 5(4), 290-298.

Kumar, P., Singh, N.P., Mathur, V.C., 2006. Agricultural Economics Research Review 19(Conference No.) 2006, $1-22$.

Mishra, N., 2005. Eco-feminism: A global concern, Social welfare, 3-8.

Prasad, J.V.N.S., 2014. Livelihood diversification through agroforestry in India. Paper presented in World Congress on Agroforestry, New Delhi, February 10 to 12.

Rani, R., Gill, A., Bajaj, G., 2013. Constraints perceived by dairy farmers inadoption and repayment of dairy loans, J. of Ani. Re. 3(1), 75-84.

Scoones, I., 1998. Sustainable Rural Livelihoods: A Framework for Analysis,Working Paper 72, Brighton, UK: Institute for Development Studies.

Verma, S.K., Paul, S.K., 2015. Sustaining non-timber forest product (NTFPs) based rural livelihood of tribal in Jharkhand: Issues and Challenges, IASC conference.

Whitaker, Beth Elise., 1999. Changing opportunities: refugees and host communities in western Tanzania. New Issues in Refugee Research, Working Paper no. 11, UNHCR, Geneva.

Zulfikar, F., Thapa, G.B., 2015. Agricultural Sustainability Assessment at Provincial Level in Pakistan. Land use policy 68, 492-502. 